\title{
Fenntartó kezelési módok felnőttkori rosszindulatú hematológiai betegségekben
}

\author{
Udvardy Miklós dr. \\ Debreceni Egyetem, Általános Orvostudományi Kar, Belgyógyászati Intézet, Hematológiai Tanszék, Debrecen
}

\begin{abstract}
A fenntartó kezelésmódok elsősorban a gyermekkori akut lymphoid leukaemiában voltak általánosak, felnőttkorban ritkábbak. Fokozatosan alakultak ki fenntartó kezelési módok néhány felnőttkori hematológiai betegségben, például néhány lymphomában - például follicularis lymphoma, köpenysejtes lymphoma -, s az elmúlt években a myeloma fenntartó kezelése egyre jelentősebb teret nyert. Mára egyre több onkohematológiai entitás fenntartó kezelése egyre erősödő tendencia, sokszor a kezdetben csak az indukciós vagy relapsusos esetekben hatékonynak bizonyuló kis molekulák előtérbe kerülése várható fenntartó készítményként is. Myelomában a prognózisfüggő fenntartó kezelési mód, mely gyakran akár a visszaesésig tart, mára minden nemzetközi és komolyabb ajánlás része. Az elmúlt években megjelentek fenntartó kezelési módok a felnőttkori akut myeloid leukaemiában is, teljesen új elemként akár transzplantációt követően, akár a nélkül. Megváltozott az a szemlélet, hogy egy nehéz kemoterápia vagy éppen a csontvelőátültetés azért is jó, mert utána kezelésmentessé válhat a betegek túlnyomó része. Fontos az is, hogy a fenntartó kezelés ne legyen megterhelő, ne kelljen túl sok időt a kórházban tölteni, minél inkább egyszerú, akár tablettás formájú lehessen. Vannak tendenciák arra, hogy az indukció, a konszolidáció és a fenntartó kezelés (például a myeloma egyes esetei) egyre inkább kontinuumot képezzenek.
\end{abstract}

Orv Hetil. 2020; 161(38): 1623-1628.

Kulcsszavak: konszolidáció, fenntartó kezelés, leukaemia, lymphoma, myeloma

\section{Maintenance therapy in malignant oncohematology, recent advances, evolving concepts}

Maintenance therapy has been the strong and standard element of many acute lymphoblastic leukaemia protocols, used much less frequently and systematically in adult oncohematological disorders. The first adult maintenance efforts appeared in follicular and mantle cell lymphoma (mostly monoclonal antibody based), along with an early maintenance effort to prolong the plateau phase of myeloma. For the time being, after a long debate, the prognosisdependent type of consolidation and maintenance became - sometimes until relapse - the standard approach in myeloma patients. The so-called small molecules, which turned out to be effective as induction and relapse agents, are continuously moving toward maintenance settings. Moreover, maintenance efforts seem to be more and more considered and used in transplanted or some non-transplanted acute myeloid leukaemia patients as well. Nevertheless, maintenance should be patient-friendly, easy to use (e.g., tablets) by enabling short outpatient office time, done not very frequently, and as much quality-of-life-based as possible.

Keywords: consolidation, maintenance, leukaemia, lymphoma, myeloma

Udvardy M. [Maintenance therapy in malignant oncohematology, recent advances, evolving concepts]. Orv Hetil. $2020 ; 161(38): 1623-1628$.

(Beérkezett: 2020. április 15.; elfogadva: 2020. május 4.)

\section{Rövidítések}

$\mathrm{AML}=$ akut myeloid leukaemia; ARA-C $=($ arabinosylcytosine $)$ citozin-arabinozid; $\mathrm{CD}=$ (clusters of differentiation) differenciációs klaszter (a monoklonális antitest által felismert vagy tá- madott antigénrégió általánosan elterjedt terminológiája); $\mathrm{FLT}_{3}=($ fms-like tyrosine kinase 3$)$ fms-szerü tirozin-kináz-3; $\mathrm{GVH}=$ (graft versus host disease) graft versus host betegség; JAK2 = Janus-kináz-2; MP = a melfalan- és prednizolonalapú, 
inkább történeti jelentőségú indukciós kezelés rövidítése myelomában; $\mathrm{MRD}=($ minimal residual disease $)$ minimális reziduális betegség

\section{Bevezetés, fogalmak}

A fenntartó kezelés a rosszindulatú vérképző szervi betegségek körében a legmarkánsabban a gyermekkori akut lymphoid leukaemia kezelésében és ellátásában jelent meg. Ez indukciós, konszolidációs és fenntartó fázisra oszlott, illetve osztható. Ez a fenntartó fázisban a már elért eredmények megtartását, a visszaesés megelőzését szolgálta. Ezt követően terjedt el egyre inkább és egyre több betegség kezelésében az indukciót követó konszolidációs kezelési mód is, melyet a fenntartó kezelés követ. Ezek elsősorban azokban a betegségekben voltak hagyományosan eróteljesek és nagy fontosságúak, amelyekben a konszolidáció és/vagy fenntartó kezelés nélkül a betegség teljes gyógyulása nem volt várható, visszaeséssel kellett számolni. Az évek során egyre világosabbá vált a definíció, hogy a konszolidációs kezelés az elért remisszió minőségét, mélységét tovább bővíti, javítja, elérheti a minimális reziduális betegség (MRD-) negativitást, a fenntartó kezelés pedig döntően a már az indukcióval vagy konszolidációval elért remissziós minőség minél további vagy végleges megőrzését célozza meg. A nagy intenzitású kemoterápiás és transzplantációs felnőttkori esetekben évtizedeken át ritka volt a fenntartó kezelés, mondván, a nagy terápiás lépések után az az előny, hogy nem kell további kezelésekre járni. Ez a helyzet mára megváltozott, és kiderült, hogy szükség lehet nagyon sok rosszindulatú vérképző betegségben konszolidációs vagy konszolidáció nélküli fenntartó kezelésre. Ezt nagyban megkönnyítette, hogy a fenntartó kezelési módok egyre inkább úgy oldhatók meg, hogy azok kevés kontaktidőt és megterhelést jelentsenek az érintett betegek számára. Mára néhány betegségben mint például az időskori myeloma - az indukciós, konszolidációs és fenntartó kezelés nem feltétlenül válik már élesen külön, akár funkcionális egységként, egyfajta kontinuumként is kezelhető. Az összefoglaló közlemény áttekinti a legfontosabb felnőttkori rosszindulatú vérképző szervi betegségekben ajánlott fenntartó kezeléseket, illetve azok viszonyát a megelőző vagy konszolidációs kezelésmódokhoz.

\section{Myeloma multiplex}

Évtizedekkel ezelőtt az MP- (melfalan, prednizolon, ciklikusan, per os) protokollal nem volt elérhetó érdemi remisszió, csak úgynevezett platófázis, amely igazából nem volt hosszú időtartamú, de néhány hónap túlélés eredményt talán így is el lehetett érni. Ezt a platófázist akkoriban próbáltuk megnyújtani, kezdetben leginkább interferonkészítmények alkalmazásával. Az interferonok nagyon hatékonyak is tudtak lenni, de ez csak az esetek legfeljebb egyharmadában volt meggyőző [1]. Ambu- lánsan jól alkalmazható volt, heti 2-3 subcutan injekció, és persze a tipikus mellékhatásokkal, láz, izomfájdalom. Kezdetben azt hittük, hogy azok a myelomások profitálnak ebből az interferonalkalmazásból, akiknél van ilyen mellékhatás is, illetve megjelentek molekuláris módszerek is annak prognosztizálására, hogy az interferon fenntartó kezelés hatékony lesz-e. Később kiderült, egyik módszer sem felelt meg igazán az elvárásoknak. Így mára az interferonkezelés visszaszorult, vagy csak kivételes esetekben jön számításba [1]; biztosan nem alkalmazható allogén transzplantáció után, illetve a vesemúködés olyan zavarában, amely nagy fehérjeürítéssel jár, továbbá szervtranszplantált betegekben sem.

A myeloma történetében a második nagy fenntartó kezelési éra a zömmel francia adatok alapján megindított talidomid fenntartó kezelés volt $[1,2]$. Ezt elsősorban autológ transzplantáció után adták. Hatékony volt a betegek egy csoportjában, de az is kiderült, hogy a 4/14 transzlokáció esetén, ha kialakult visszaesés, akkor az - az akkori terápiával - gyakran refrakternek bizonyult. Így mára a talidomid kivonult a myeloma fenntartó kezelési arzenálból. A proteaszómagátlók (klasszikusan a bortezomib) - különösen a p53-pozitív myelomákban adva - is hatékony eszközök, melyek javaslata a myeloma genetikai altípusának figyelembevételével ma is él, akár a relapsusig $[2,3]$. Persze modernebb készítmények, tabletták is rendelkezésre állnak, például az ixazomib mellett ez a kezelésmód sokkal könnyebben illeszthető a jó minőségú életvitelhez. Időközben olasz adatok azt mutatták, hogy az autológ transzplantáció után adott 2-3 ciklus indukciós típusú kezelés ismétlése, azaz konszolidáció alkalmazása 10-15\%-ot mélyít a remisszió minőségén $[2,3]$. Ezt követően adtak lenalidomidot. A standard prognózisú myeloma fenntartó kezelésében ma valóban meghatározó a lenalidomid alkalmazása; francia ajánlások eredetileg 2 évet javasoltak, míg az újabb ajánlások akár a relapsusig alkalmazzák - a leggyakoribb dózis napi $10 \mathrm{mg} 21$ napig, 10 nap szünet, majd újabb ciklus indul. A lenalidomid fenntartó kezelés utáni relapsus hatékonyan kezelhető, persze elsősorban az innovatív antimyelomás készítményekre támaszkodva [1]. A lenalidomid fenntartó kezelés ismert módon okozhatja a másodlagos malignitás számbeli növekedését, kb. 10000 betegév/16 számban. Ezek elsősorban bőr-, tüdő-, myelodysplasia; ennek kockázata függ a beteg életkorától és a megelőző alkilálókezelésektől is [3]. A kezelés egyértelműen hatékony, a másodlagos tumor veszélye alulmúlja a relapsusmegelőző hatékonyságot. Ennek ellenére minden egyes esetben egyedileg kell eldönteni, hogy a ténylegesen nem megterhelő tablettás kezelési módot tudjuk választani, az előnyök és kockázatok ismeretében, a beteggel egyeztetve, kinél alkalmazzuk, s meddig. A nemzetközi törekvés az, hogy lenalidomid fenntartó kezelés történjen, lehetóleg mindenkinél, akár transzplantációt követően, akár transzplantáció nélkül elért remiszszió fenntartásában. A lenalidomid és második tumor összefüggése vezetett oda, hogy elsősorban az Egyesült 
Államokban, de most már Európában is az időskori myelomások indukciós kezeléséből a melfalanalapú indukció helyett modern tripletek kerülnek be az indukcióba. A 80 év körüli vagy nagyon fragilis biológiai állapotú betegek kezelése egészen sajátos: az indukció lenalidomid és dexametazon kombinációja, melyből a dexametazon dózisa egyre csökken, majd elmarad, és megmarad folytatásként a lenalidomid egyedül. Ez esetben tehát tényleg egybeolvad az indukció, a konszolidáció és a fenntartó kezelés. Általánosságban megállapítható, hogy a modern indukciós kezelésmódok, a transzplantáció, a konszolidáció és a fenntartó kezelés szemlélete funkcionális, egymástól függő egységet képez, s egyre inkább tényező az, hogy milyen indukció után alkalmazható hatékony fenntartó kezelés. Teljesen általános az, hogy akinél csak lehet, történjen fenntartó kezelés, életkorától, biológiai állapotától függően persze finoman módosítva, de lehetőleg tartósan a visszaesésig. Ez azért is lehetséges, mert az új refrakter myelomás kombinációk újabb, akár 40-50 hónapos tünetmentes időszakot érhetnek el a lenalidomid fenntartó kezelés után is, így nem rontják a visszaesés kialakult helyzetben a betegség további javításának lehetőségeit [1-3].

\section{Anti-CD20- (döntôen rituximab-) alapú, illetve innovatín fenntartó terápiák lymphomákban}

Follicularis lymphomában terjedt el legelőször a havi rendszerességú rituximab-, anti-CD20-alapú fenntartó terápia. Ennek megítélése nagyon pozitív volt - például a hazai HUSOM-tanulmány eredményei alapján [4]: megnyújtotta a progressziómentes túlélést, késleltette a visszaesést -, de nem ennyire egyértelműek a teljes túlélés megnyújtására vonatkozó adatok. Nem kevés a mellékhatás, alacsony az immunglobulinszint, több a légúti hurut, időnként alacsony a fehérvérsejtszám. Kisebb mértékben csökken az influenza-védőoltás hatékonysága, s kifejezetten romlik a tokos Gram-pozitív baktériumok elleni vakcináció effektivitása is. Az MRD-vizsgálatok korában, időszakában a felfogás úgyis változhat, hogy amíg ez negatív, nem feltétlenül szükséges fenntartó kezelés, de amint eltérés jelentkezik, az anti-CD20monoterápia késleltetheti a klinikai visszaesés kialakulását [5]. Az elmúlt években számos kis molekula megjelent a follicularis lymphoma kezelésében, közülük különösen az ibrutinib lehet alternatíva a fenntartó kezelésben is follicularis lymphoma esetén. Vannak ajánlások, amelyek már inkább ezt a fenntartó kezelést javasolják, de erre vonatkozó biztos evidencia még nincs. Hasonló a helyzet köpenysejtes lymphomában, ahol az anti-CD20 (rituximab)-alapú fenntartó kezelés ma is standard terápiának tekinthető $[6,7]$. Itt is megjelenik az a koncepció, hogy ameddig az MRD-eredmény negatív, nem szükséges ilyet adni, de amint pozitív, el kell kezdeni az adását, ami késleltetheti a jelentősebb relapsus kialakulá- sát. Köpenysejtes lymphomában is feltételezhető, hogy az erre vonatkozó tanulmányok lezárta után az ibrutinib szerepe a fenntartó kezelésben is jelentős lesz - nem csak a relapsusban, mivel a relapsus kezelésére vannak akár hatékonyabb alternatív molekulák (akalabrutinib, zanabrutinib stb.). Összefoglalva megállapítható, hogy e két lymphomában az anti-CD20 típusú fenntartó kezelés ma is standard terápiás lépésnek tartható, de az idő́k változása az időzítést összekapcsolhatja az MRD-vizsgálatokkal, illetve várható, hogy az újabb, kis molekulasúlyú készítmények előbb-utóbb átveszik e kezelési mód szerepét [6-8].

\section{Hodgkin-lymphoma}

Klasszikusan nem tartozott - nagyon jó gyógyulási aránya miatt és a gyógyulások definitív, végleges jellegét figyelembe véve - a fenntartó kezelés tipikus esetei közé. A brentuximab vedotin megjelenésével azonban az autológ transzplantációra szoruló refrakter Hodgkin-lymphomás esetekben a beavatkozást követően e készítménnyel végeztek fenntartó kezelést. Az AETHERA-tanulmányban a progresszió megjelenését lehetett késleltetni; a túlélést nyújtó hatás nem volt mindig ennyire meggyőző, bár egyedi, kifejezetten refrakter, rossz prognózisú esetekben jó válaszokról is beszámoltak. Jelentős mellékhatás volt a polyneuropathia $[9,10]$, mely súlyos, akár motoros típusú is lehet. Összességében a kezelésmód hatékony, különösen a rossz prognózisú refrakter esetekben, de inkább konszolidációnak felel meg, mint fenntartó kezelésmódnak.

\section{Akut myeloid leukaemia}

Bár a fenntartó kezelés inkább a lymphoid leukaemia jellegzetessége volt, az akut myeloid leukaemiában (AML) is van ennek története. Kézenfekvőnek látszott az oralis 6-merkaptopurin és metotrexát adása AML-ben is, de ezzel túlélésjavulás nem volt elérhető.

Az egyik régi törekvés a kis dózisú ARA-C indukciós kezelés (147 beteg, az első komplett remissziót követően, $10 \mathrm{mg}$ pro négyzetméter, 12 óránként 12 napig, 8 ciklus), ez azonban nem eredményezett túlélésjavulást [11]. Történt számos más kombináció, többnyire ARAC plusz kis dózisú vinkrisztin, daunorubicin, etopozid, tioguanin, amszakrin, ciklofoszfamid stb. kombinációkkal, de az eredmények nem meggyőzőek [12, 13]. Ugyanilyen volt az interferon alkalmazása, illetve az Európai Gyógyszerügynökség által korábban e célra befogadott interleukin-2 is évtizedekkel ezelőtt, melyek azonban bizonyítható túlélésjavulást nem eredményeztek. Ma már nem alkalmazhatók, különösen nem allogén átültetés után $[12,14]$.

A részletesebb, korszerű prognosztikai osztályozás, a molekuláris eltérések azonban újból előhozták a fenntartó kezelés kérdését, számos új próbálkozás van [12]. E próbálkozások egy része a reziduálisbetegség-negatív 
állapot megőrzését szolgálja, de ez a kisebb volumen, kisebbik törekvés. Más esetekben a jó klinikai parciális remisszió, de még a reziduálisbetegség-pozitív esetekben is javítja a remisszió minőségét, azaz az eredeti definíció szerint ez a konszolidáció és a fenntartó kezelés egyfajta keveréke.

Nagyon meggyőző volt a $75 \mathrm{mg}$-os azacitidin oralis alkalmazással elért jó eredmény 55 éves kor fölötti indukció után valamiféle remissziót elérő AML-betegekben, 24,7 hónapos átlagos medián túléléssel, míg ez a placebokarban 14,8 hónapnak bizonyult $[15,16] . \mathrm{Ez}$ akár új standard ajánlásnak is tekinthető; a tanulmány az első vonalbeli kezelés utáni helyzetre vonatkozott, de a klinikai hematológia elindult azon az úton, hogy többedvonali kezelés, illetve transzplantáció után is történjen ilyen fenntartó kezelés. Amennyiben hozzáférhetővé válik, és jól megoldható, ez az ajánlás valószínúleg ebben az eleve rossz prognózisú korcsoportban rizikófüggetlenül is alkalmazható kell, hogy legyen [17]. Hasonló eredményeket várnak a venetoklax fenntartó alkalmazástól, de erre evidencia csak 2021 második felében várható $[12,17]$. Ugyanígy az is egy várhatóan hatékony és standard eljárás ígérete, hogy az izocitrát-dehidrogenáz-gátló egyes vagy kettes típusú mutációjának esetében az erre ható enaszidenib/ivoszidenib típusú szerekkel való még legalább kétéves fenntartó kezelés a remisszió után túléléselőnyt eredményez [18]. Bár az ezt vizsgáló tanulmányok még nem zárultak le, próbálkozások voltak myeloid leukaemiában korábban a lenalidomiddal is, de mindig mérlegelni kell a várható előny mértéke mellett a GVH-provokáció-kiváltás lehetőségének veszélyét transzplantáltakban [19].

$\mathrm{Az} \mathrm{FLT}_{3}$-pozitív esetekben a szorafenibbel vannak biztató adatok, de vannak a kvizartinibbel is, fóként a transzplantáció utáni helyzetekben. Ugyancsak biztató adatok vannak e helyzetben gilteritinibbel [20-22].

A venetoklax az időskori betegek elsődleges kezelésében is nagyon fontos, és szerencsés, ha a kezelést a jó eredmény elérésekor - ha lehetséges - nem hagyjuk abba, hanem kis dózissal folytatjuk kvázi fenntartó jelleggel $[12,17]$.

A decitabinnal is vannak kedvező tapasztalatok, illetve a nagyon nagy mértékben refrakter esetekben közel 20\%-os túléléselőny biztosítható nivolumab alkalmazásával a 18 hónapnál mérve. Az ezzel kapcsolatos klinikai tapasztalat még nem elégséges, vélhető azonban, hogy a területen nagy fejlődés várható [23].

Összességében megállapítható, hogy AML-ban a fenntartó kezelés az esetek jelentős részében az új standard eljárások közé kerülhet; különösen fontosak a rossz molekuláris prognózisú esetek, az $\mathrm{FLT}_{3}$-pozitívakban az $\mathrm{FLT}_{3}$-gátlás, valamint transzplantáció után, és az azacitidin 55 éves kor felett. Feltehetően a rossz prognózisú esetekben transzplantáció után is a speciális molekuláris fenntartó jellegű kezelési törekvések közé sorolható az izocitrát-dehidrogenáz-mutáció-gátlók kiterjesztett idejü alkalmazása is [12].

\section{Krónikus lymphoid leukaemia}

A legtöbb próbálkozás lenalidomiddal és rituximab típusú antitestkezeléssel (például ofatumumab) történt. Az előbbinek viszonylag sok a mellékhatása, és a túlélés javítása nem bizonyított. A rituximabbal vannak a közelmúltban lezárult, a progressziómentes túlélést javító hatásról szóló tanulmányok is, de a nemzetközi állásfoglalások összességében nem tekintik standard módon szükséges beavatkozásnak. Bár a remisszió időtartama e kezelésmódok mellett megnyúlik, a teljes túlélésben nem sikerült előnyt igazolni [24]. Ezt jelentős részben az is magyarázza, hogy a korábbi krónikus lymphoid leukaemia fenntartó kezelési tanulmányok a maitól nagymértékben eltérő indukciós kezeléseket követően kerülnek alkalmazásra. Az új típusú, első vonalbeli kezelésmódok után, melyek hatása lényegesen tartósabb, nincs még elég adat, hogy milyen fenntartó kezelés szükséges, vagy szükséges-e egyáltalán.

\section{Krónikus myeloid leukaemia}

A tirozin-kináz-gátló kezelés döntően megváltoztatta a betegség lefolyását, és úgy tûnik, hogy legfőbb törekvése nem a fenntartó kezelés, hanem a tirozin-kináz-gátló kezelés biztonságos körülmények közötti felfüggesztése.

\section{Polycythaemia vera}

A polycythaemia kezelése általában életre szóló vérlebocsátás, ha kell, cytoreductiv kezelés és egyre inkább valamilyen innovatív terápia. Nagy rizikó és fiatal életkor esetében (nagy JAK2-allél-teher) a ropeginterferon-alfa2 b alkalmazását - mely molekuláris remisszióban, illetve annak elérését követően nagyon kis adagban is folytatható - nem igazán jó abbahagyni. Ez a nagyon kis adag lehet például 6-8 hetente $250 \mu \mathrm{g}$ - ezt akár egyfajta fenntartó kezelésnek is gondolhatjuk. A hagyományos cytoreductiv terápiára refrakter polycythaemia esetében választhatjuk a ruxolitinibet, melyre hosszú távú tapasztalat vagy ajánlás még nincs [25].

\section{Felnöttkori akut lymphoid leukaemia}

A gyermekkori esetekben a klasszikus fenntartó kezelés döntően merkaptopurin és kis dózisú metotrexát heti/ havi gyakoriságú adását jelentette, akár hosszabb időn keresztül. Felnőttkorban az AML-tól eltérően sokféle indukciós protokoll létezik, melyeknek ebből következően kissé eltérő, bár főbb vonalakban mégis hasonló elemei a konszolidációs és a fenntartó fázis [26].

A konszolidációnak 3 fó formája van: az allogén transzplantáció, az autológ és a kemoterápiás konszolidáció. Elég egységes adatok vannak arra, hogy a kemoterápiás konszolidáció (antraciklinek, ARA-C, ciklofoszfamid stb.) eredményei 5 éves túlélésben 40-60\%-osak. 
Ez autológ transzplantációs konszolidációval statisztikusan szignifikáns mértékben nem javítható [26].

$\mathrm{Az}$ allogén transzplantáció előnye a lényegesen kevesebb relapsus, hátránya a korai mortalitás, és nagy sokaság tekintetében az eredmények 5 vagy 10 éves túlélésben nagyon hasonlóak a kétféle eljárással. E tekintetben nincs igazán minden szempontot kielégítő prospektív, a túlélést összehasonlító tanulmány. Nagy esetszámok áttekintése azonban azt mutatja, hogy nagy rizikójú felnőttkori akut lymphoid leukaemia (például sejtszám, citogenetika, molekuláris eltérések stb.), illetve 35 éves életkor alatti csoport és jó donor esetén az allogén konszolidációs eredmények jobbak, mint a kemoterápiásakéi.

Allogén csontvelő átültetése után felnőttkori akut lymphoid leukaemiában nincs standard fenntartó kezelésre ajánlás. Ez alól egyetlen kivétel a Philadelphia-pozitív akut lymphoid leukaemia, melyben a transzplantációval vagy a nélkül elért remissziót követően hosszabb ideig molekuláris követéssel tirozin-kináz-gátlók adása indokolt, ami ez esetben egyértelmúen fenntartó kezelésnek minősül [26].

A felnőttkori Philadelphia-negatív akut lymphoid leukaemia fenntartó kezelése nagyon hasonlít a gyermekkoriéhoz: naponta kis dózisú 6-merkaptopurin, heti 1 alkalommal metotrexát, havonta 1 prednizolon, vinkrisztin adása 2 vagy 3 éven keresztül. Nincs bizonyíték arra, gyermekkori adatok alapján, hogy az 5 éves fenntartó kezelés hatékonyabb, mint a 3 éves. 2020-ban a fenntartó kezelést MRD-monitorozni szükséges és érdemes, ami segít az egyedi optimális időtartam megállapításában és a relapsus molekuláris szintü, korai felismerésében [26].

\section{Következtetések}

Az irodalmi összefoglaló közlemény áttekinti azon onkohematológiai betegségek körét, melyekben a fenntartó kezelés gyakorlata az elmúlt években megszokott gyakorlattá vált, de felhívja a figyelmet az ajánlásokban bekövetkezett vagy a közeljövőben várható változásokra. Lényeges paradigmaváltás, hogy számos betegségben (például AML, különösen transzplantáció után) megjelent a konszolidáció és a fenntartó kezelés, bizonyos kockázati vagy életkori alcsoportokban akár standard eljárásként. A másik fontos paradigmaváltás az innovatív, kis molekulasúlyú kezelési módok megjelenésével az indukciós kezelési módok, a konszolidáció, illetve a fenntartó kezelés egységbe foglalása, egymástól függése vagy a folytatólagos közelítés és alkalmazás módja. Az innovatív, kis molekulájú kezelési módozatok az életminőség megőrzése szempontjából is előnyösek, s ez nagyon fontos a fenntartó kezelések esetében. Az összefoglaló célja e törekvések hazai gyakorlattá válásának előmozdítása, gyorsítása.
Anyagi támogatás: A szerző anyagi támogatásban nem részesült.

A cikk végleges változatát a szerző elolvasta és jóváhagyta.

Érdekeltségek: A szerzőnek nincsenek érdekeltségei.

\section{Irodalom}

[1] Morè S, Corvatta L, Maracci L, et al. Developments in consolidation and maintance strategies in post-remission multiple myeloma. Expert Rev Hematol. 2020; 13: 351-362.

[2] Diamond B, Maclachlan K, Chung DJ, et al. Maintenance therapy and need for cessation studies in multiple myeloma: focus on the future. Best Pract Res Clin Haematol. 2020; 33: 101140.

[3] Ishida T, Kimura H, Ozaki S, et al. Continuous lenalidomide treatment after bortezomib-melphalan-prednisolone therapy for newly diagnosed multiple myeloma. Ann Hematol. 2020; 99: 1063-1072.

[4] Schneider T, Rosta A, Losonczy H, et al. Efficacy and tolerability of a 2-year rituximab maintenance therapy in patients with advanced follicular lymphoma after induction of response with rituximab-containing first line-regimens (HUSOM Study). Pathol Oncol Res. 2018; 24: 199-205.

[5] Klener P, Salek D, Pytlik R, et al. Rituximab maintenance significantly prolongs progression-free survival of patients with newly diagnosed mantle cell lymphoma treated with the Nordic MCL2 protocol and autologous stem cell transplantation. Am J Hematol. 2019; 94: E50-E53.

[6] Maddocks K. Update on mantle cell lymphoma. Blood 2018; 132: 1647-1656.

[7] Kaplan LD, Maurer MJ, Stock W, et al. Bortezomib consolidation or maintenance following immunochemotherapy and autologous stem cell transplantation for mantle cell lymphoma: CALGB/Alliance 50403. Am J Hematol. 2020; 95: 583-593.

[8] Rozental A, Gafter-Gvili A, Vidal L, et al. The role of maintenance therapy in patients with diffuse large B cell lymphoma: a systematic review and meta-analysis. Hematol Oncol. 2019; 37: 27-34.

[9] Kort J, Chidiac A, El Sayed R, et al. Safety and efficacy of four cycles of brentuximab vedotin as consolidation after autologous peripheral stem cell transplantation in relapsed/refractory Hodgkin lymphoma. Leuk Lymphoma 2020; 61: 1732-1735.

[10] Moskowitz CH, Nademanee A, Masszi T, et al. Brentuximab vedotin as consolidation therapy after autologous stem-cell transplantation in patients with Hodgkin's lymphoma at risk of relapse or progression (AETHERA): a randomised, double-blind, placebo-controlled, phase 3 trial. Lancet 2015; 385: 1853-1862. [Correction: Lancet 2015; 386: 532.]

[11] Ferrero D, Crisà E, Marmont F, et al. Survival improvement of poor-prognosis AML/MDS patients by maintenance treatment with low-dose chemotherapy and differentiating agents. Ann Hematol. 2014; 93: 1391-1400.

[12] Molica M, Breccia M, Foa R, et al. Maintenance therapy in AML, the past, the present and future. Am J Hematol. 2019; 94: 1254-1265.

[13] Choi YW, Jeong SH, Ahn MS. Oral maintenance chemotherapy with 6-mercaptopurine and methotrexate in patients with acute myeloid leukemia ineligible for transplantation. J Korean Med Sci. 2015; 30: 1416-1422.

[14] Lehman C, Zeis M, Uharek L. Activation of natural killer cells with interleukin 2 (IL-2) and IL 12, inreases perforin binding and subsequent lysis of tumour cells. Br J Haematol. 2001; 114: 660-665. 
[15] Maples KT, Sabo RT, McCarty JM, et al. Maintenance azacitidine after myeloablative allogeneic hematopoietic cell transplantation for myeloid malignancies. Leuk Lymphoma 2018; 59: 2836-2841

[16] De Lima M, Oran B, Champlin RE, et al. CC-486 maintenance after stem cell transplantation in patients with acute myeloid leukemia or myelodysplastic syndromes in AML and MDS. Biol Blood Bone Marrow Transpl. 2018; 24: 2017-2024.

[17] Wei HA. Maintenance therapy for AML, are we there yet? Blood 2019; 133: 1390-1392.

[18] Di Nardo CD, Stein EM, de Botton S, et al. Durable remissions with ivosidenib in $\mathrm{IDH}$-mutated relapsed or refractory AML. N Engl J Med. 2018; 378: 2386-2398.

[19] Kotla V, Goel S, Nischal S, et al. Mechanism of action of lenalidomide in hematological malignancies. J Hematol Oncol. 2009; $2: 36$

[20] Burchert A, Bug G, Finke J, et al. Sorafenib as maintenance therapy post allogeneic stem cell transplantation for $\mathrm{FLT}_{3}$-ITD positive AML, results from the randomized, double-blind, placebo-controlled multicentre Sormain trial. Blood 2018; 132(Suppl 1): 661.

[21] Sandmaier BM, Khaled S, Oran B, et al. Results of a phase 1 study of quizartinib as maintenance therapy in subjects with acute myeloid leukemia in remission following allogeneic hematopoietic stem cell transplant. Am J Hematol. 2018; 93: 222-231.
[22] Perl A, Martinelli G, Cortes J. Gilteritinib significantly prolongs overall survival in patients with $\mathrm{FLT}_{3}$-mutated $\left(\mathrm{FLT}_{3} \mathrm{MUT}+\right)$ relapsed/refractory (R/R) acute myeloid leukemia (AML). Results from the phase 3 ADMIRAL trial. Cancer Res. 2019; 3: 392-393.

[23] Stahl M, Goldberg AD. Immune checkpoint inhibitors in acute myeloid leukaemia: novel combinations and therapeutic targets. Curr Oncol Rep. 2019; 21: 37.

[24] Lee $\mathrm{CH}$, Chen $\mathrm{PH}$, Lin $\mathrm{C}$, et al. A network meta-analysis of maintenance therapy in chronic lymphocytic leukaemia. PLoS ONE 2020; 15: e226879.

[25] Gisslinger H, Klade C, Georgiev P, et al. Ropeginterferon alfa-2b versus standard therapy for polycythaemia vera (PROUD-PV and CONTINUATION-PV): a randomised, non-inferiority, phase 3 trial and its extension study. Lancet Haematol. 2020; 7: e196e208. [Correction: Lancet Haematol. 2020; 7: e279.]

[26] Jabbour E, Pui CH, Kantarjian H. Progress and innovations in the management of adult acute lymphoblastic leukaemia. JAMA Oncol. 2018; 4: 1413-1420.

(Udvardy Miklós dr., Debrecen, Nagyerdei krt. 98., 4032 e-mail: udvardy.miklosdr@gmail.com)

\section{„Verbum omne refert in quam partem intellegas." (Minden szónál az a fontos, hogyan érted.)}

A cikk a Creative Commons Attribution 4.0 International License (https://creativecommons.org/licenses/by/4.0/) feltételei szerint publikált Open Access közlemény, melynek szellemében a cikk bármilyen médiumban szabadon felhasználható, megosztható és újraközölhető, feltéve, hogy az eredeti szerző és a közlés helye, illetve a CC License linkje és az esetlegesen végrehajtott módosítások feltüntetésre kerülnek. (SID_1) 